\title{
Determinants of Adoption of Physical Soil and Water Conservation Technologies in Dengab Micro-Watershed, Ethiopia
}

\author{
Enawugaw Alemayehu \\ Basoliben Woreda Trade, Industry and Development Office, Ethiopia \\ Yenetila Alamneh $(\mathrm{PhD})$ \\ Department of Agricultural Economics, Debre Markos University, Ethiopia \\ Derjew Fentie $(\mathrm{PhD})$ \\ Department of Agricultural Economics, Debre Markos University, Ethiopia
}

\begin{abstract}
Land degradation due to soil erosion is the critical factor that contributes for a decline in production and productivity. To reverse the situation the concerned government agencies and NGOs are undertaking some measures in some degraded areas of the highlands including the study area. However, the adoption of soil conservation technologies by farmers is hindered by a number of factors. Therefore, the objective of this study was to identify and examine the socio-economic, institutional and physical factors that determine the adoption of physical soil and water conservation technologies in the study area. To address the objective of the study both primary and secondary data were collected. Three-stage sampling technique was used to draw the sample respondents for the study. The primary data were collected from 77 sample households by using stratified probability sampling method. In line with this, the combination of data collection methods by the help of agricultural extension agents' interview using questionnaires and focus group discussions were employed. The binary logit model was used to identify the factors affecting the adoption of physical soil and water conservation technologies. In addition, descriptive statistics were also used. The result of logit model indicated that education level of household head, land holding, training, slope, land ownership, extension contact and perception positively and significantly affected the adoption of physical soil and water conservation technologies at conventional probability levels. While, age, distance and fertility affected the adoption of these technologies negatively and significantly. Therefore, any soil and water conservation plans should consider the farmers' willingness and factors impeding their practices before introducing these technologies; create awareness on the farmers about the overall benefits and challenges of the technologies and follow down-top approach and include farmers in any decision making processes.
\end{abstract}

Keywords: adoption, improved PSWC measures, Determinants, Basoliben District

DOI: $10.7176 / \mathrm{JAAS} / 69-02$

Publication date:October $31^{\text {st }} 2020$

\section{INTRODUCTION}

Soil degradation is a worldwide environmental crisis that requires urgent interference measures. It is responsible for $84 \%$ of corrupted land (Blanco and Lal, 2008). The principal causes of soil degradation are rainfall and wind which causes soil erosion leading to low agricultural production, hence food insecurity, underfeeding and scarcity (FAO, 1986). The majority of Sub-Saharan Africa's population lives in rural areas, where poverty and scarcity are most harsh, almost all rural households depend directly or indirectly on agriculture (Rehema, 2014).

Agriculture in Ethiopia is the base of the country's economy accounting more than $50 \%$ of gross domestic product (GDP), $84 \%$ of national export and $80 \%$ of total employment (Meseret \& Amsalu, 2017). However, in recent times, there is rising concern that soil erosion seriously limits agricultural sustainability in Ethiopia (Gessesse et al., 2015). Agriculture is the main source of income in Ethiopia. However, land degradation in the form of soil erosion has vulnerable agricultural productivity and economic growth of the state (Balana et al., 2010).

Agricultural land is a limited resource in the highlands of Ethiopia. It constitutes the vital base of rural livelihoods. However, its sustainable use is highly exaggerated (among other factors) by bio-physical and institutional aspects of land (Teshome et al., 2016). The living conditions of the rural poor in Ethiopian highlands have been decline because of low agricultural productivity caused by increasing deterioration of the quality and quantity of agricultural land resources (Anley et al., 2007).

The population in the rural areas is growing and more food is necessary to feed this population. On the other hand, the land sizes used by each of the farmers are reducing. These situations enforced the farmers to use the land intensively throughout the year that has resulted in soil degradation. Soil degradation in revolve encompasses mineral running down, poor physical (low water retaining ability) and biological conditions of soil (Melkie, 2016).

The dilemma is extremely severe mainly in steep lands where rain fed agriculture constitutes the main income of the people. Land degradation is the main course of action at the bottom land of the watersheds where there is a 
waterlogged soil, in this part of the watershed the soil will be simply removed by sheet and rill erosion and the development of gullies (Kebede et al., 2016)

The beginning of SWC technologies may not guide to sustainability and treatment except the farmers progress to final adoption, where farmers began to integrate the measures with their farming system. Though, the outcome of researches in several parts of the country indicated that the adoption rates of conservation technologies are far below the anticipation (Mulie, 2012).

There have been huge efforts to deal with the difficulty of soil erosion in Ethiopia since 1970s following the rate of food shortage and drought. Since then, the government has given considerable focus on SWC technologies for treatment of land resources (Assefa \& Bork, 2015). A large number of protections, treatment and forestation campaigns were undertaken through Food-For-Work (FFW) programs. Nevertheless, the efforts have not been widespread and didn't convey important changes as predictable (Teshome et al., 2016). This is because the farmers were completely unobserved from decision making during the selection, planning and implementation processes of SWC measures and the activities were undertaken without interest. Consequently, it forced the farmers to removed SWC structures following the change of FFW program in 1991. Similarly, studies conducted in varied parts of Ethiopia by Tesfaye \& Brouwer (2012) reported that the farmers were considered unaware of SWC technologies and have been given little attention in decisions making processes related to SWC technologies.

Efficient protection and conservation of SWC can be realized only when farmers accept and deicide on the benefits of SWC technologies and aggressively concerned in the implementation and protection processes. The decisions of farmers to apply and supervise natural resources highly depend on their perception of the countryside (Assefa \& Bork, 2015). Certainly, farmers can improve the technologies to their own actual situations (Teshome et al., 2016). Their perception and participation also varies from place to place and from household to household due to different interactive factors. Thus, a better understanding of factors that influence farmers' perception and motivation towards SWC is very essential for designing and implementation of efficient, effective and people friendly technologies (Derjew et al., 2013).

Over the last four decades, the government of Ethiopia and a collection of donors have been promoting soil and water conservation (SWC) technologies for civilizing agricultural productivity, household food security, and rural livelihoods, while at the same time mitigating environmental degradation. Smallholders' agriculture in the country is nevertheless characterized by widespread fall down to make sufficient SWC and soil refill investments in order to maintain the output of farmlands (Teshome et al., 2016).

The regional government and other organizations are undertaking activities to mitigate the problems and the constraints faced; however, without adequate quantitative information on the magnitude of the problem, causal factors and the effort directed at solving the problem, appropriate policies cannot be effectively designed and implemented (personal communication with the District Agricultural Officer, August, 2018).

For the last five years the most widely practiced PSWC measures in the study area are the water way, cutoff drain, fanajuu and biological plantation on waterway and fanajuu, their impacts on productivity of the soils is more appropriate to farmers. The efforts put towards promotion of technologies so far seem below the thresholds which have limited the sustained use of natural resources for a better production. Therefore; developing PSWC measures that are suitable to the local environments and executing them in an efficient way is an issue of sustainability that needs an integrated effort of the government, researchers, NGOs, the general public, and other concerned bodies.

However; reports of Basoliben District Agricultural Office (2018) and the informal field observation indicated that the adoptions of the newly introduced/improved PSWC technologies are too low like in many parts of the country.

Empirical studies on the adoption of soil and water conservation practices revealed that there are a number of factors that can be loosely categorized as personal, physical, socio economic and institutional which influence farmers to adopt and not to adopt (Atnafe et al., 2015).

In the study area rapid population growth had forced farming families to expand their fields to grazing lands and fragmentation of farm lands. As a result, large areas, which are once under grazing grass cover, are exposed to heavy soil erosion and serious threat to sustainable agriculture and human health. Water is essential for human life. But this precious resource is depleted as a result of in efficient use of natural resources in the watershed.

Dengab Micro-Watershed is one of the watersheds of Basoliben District, East Gojjam Zone of the Amhara Region where Physical Soil and Water Conservation (PSWC) practices have been promoted during the last five years by the help of Sustainable Land Management (SLM) project. Though, the level of adoption of PSWCs by farmers is not to the extent it should be due to various socio-economic, institutional, physical and demographic factors. Therefore this study is initiated to identify factors that determine adoption of physical soil and water conservation practices in Dengab Micro-Watershed of Basoliben District. 


\section{MATERIALS AND METHODES}

Description of the Study Area

Location, Topography and Altitude

Dengab Micro- watershed is one of the smallest watersheds in Basoliben District, East Gojjam zone of the Amhara Regional State. Yejubie is the district capital which is $317 \mathrm{~km}$ far from North of Addis Ababa. Geographically, it is located at $10^{\circ} 15^{\prime} 95^{\prime \prime}$ to $10^{0} 21^{\prime} 08^{\prime \prime} \mathrm{N}$ latitude and $37^{0} 76^{\prime} 45^{\prime \prime}$ to $37^{0} 78^{\prime} 46^{\prime \prime} \mathrm{E}$ longitudes. The watershed covers a total area of 660.34 ha.

\section{Figure 1: Location map of the study area}

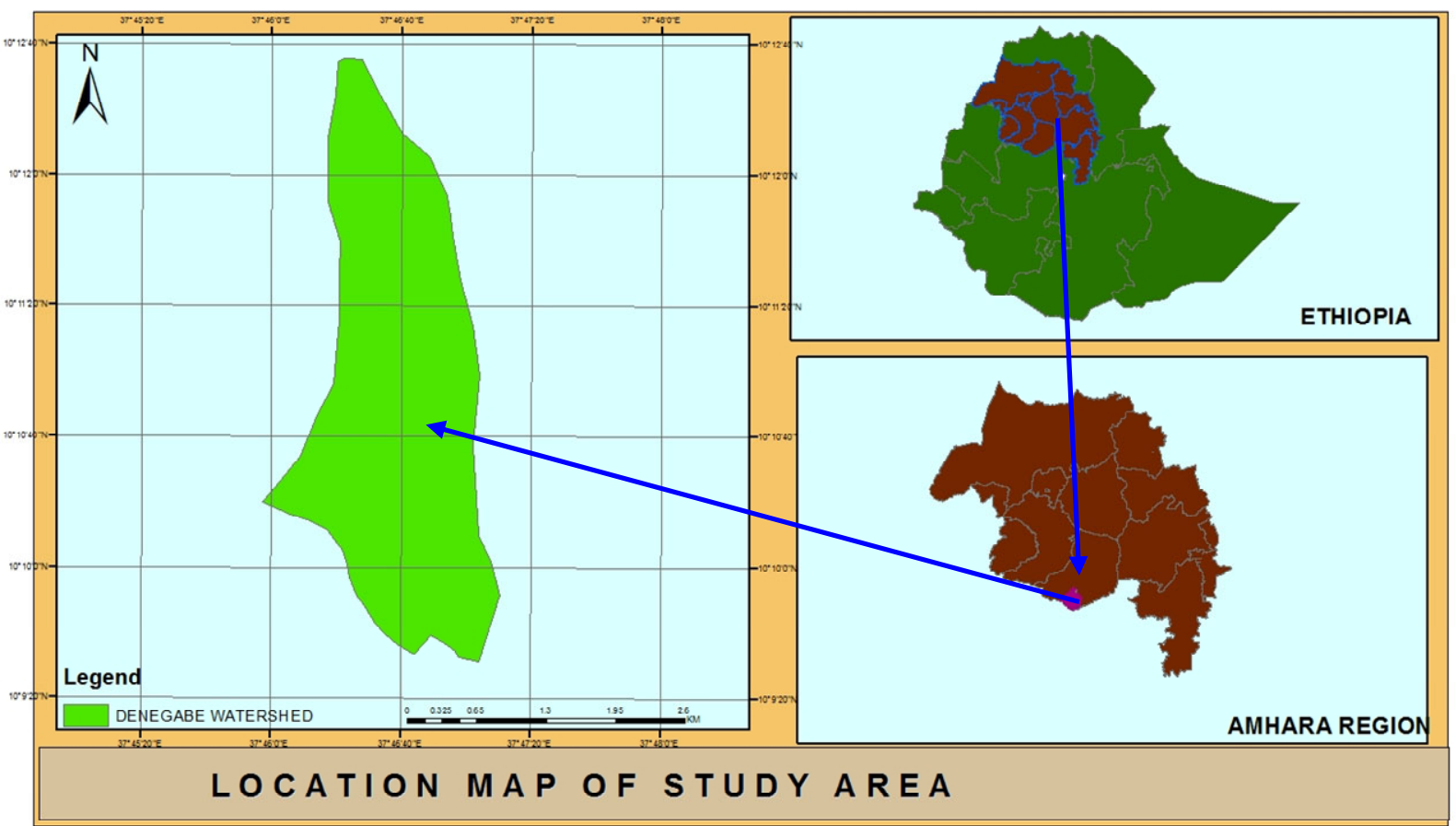

Source: Adapted from Ethio. GIS (2018)

Dengab Micro Watershed is found in the north western highlands of Ethiopia. There are four types of land forms based on their slope. These are mountainous (16-30\% slope), hill (8-15\% slope), gentle (3- $8 \%$ slope) and flat or level (0-3\% slope). The study area is found at 2245-2346 meter above sea level; so, it is assigned in Woina Dega Zone.

Rainfall pattern of the areas is unimodal, with much of the rainfall occurring between June and September. Annual rainfall is between $900-1200 \mathrm{~mm}$. The mean annual temperature in the watershed is between $14-16^{\circ} \mathrm{c}$ or on average 15 degree centigrade.

According to Amhara Digital Elevation Model (DEM) extraction (2018), the most dominant soil types of Basoliben District are Nitisols, Lendizans, Lithosols, Vertisols, Cambisols, Acrisols, and phaeozems. Among the above soil types Vertisols cover the most dominant areas in Dengab Micro-watershed.

Dengab Micro-watershed has the total area of 660.34 hectare which comprised $63.13 \%$ crop land, $9.31 \%$ vegetation cover (forest and bush land), $20.25 \%$ grazing land, $5.87 \%$ settlement and the rest $1.44 \%$ covered by others such as gullies, roads, hill sides (mountainous areas) (Yegelaw Kebele Agricultural and Rural Development Office, 2018).

\section{Materials used}

Materials necessary to conduct the study were:

$>$ Digital camera: To collect different soil and water conservation practices constructed and existing measure in the study watershed.

$>$ Global positioning system (GPS): to measure the altitude, longitude and latitude.

\section{Data Types, Source and Methods of Data Collection}

For this study both relevant qualitative and quantitative data were collected from primary and secondary sources. The primary data were collected from 77 sample respondents through formal survey using structured questionnaire. 
In addition, discussion with key informants was carried out. During discussion, watershed teams, kebele chairperson and district natural resources expert/ head, religious leaders, elders, targeted farmers' and DAs using a supporting checklist have participated. Secondary data sources of information used for this study includes documented materials such as reports, which was obtained from the District Agricultural offices, training manuals, literatures including previously made researches on similar topics, published and unpublished materials.

\section{Sampling Procedure and Sample size}

Three-stage sampling technique was used to draw the sample respondents for the study. First, out of the total number of 22 Kebeles in the District one Kebele (Yegelaw) was selected purposively. This was done based on the discussion with the District Agriculture Office (due to a reason that in the kebele there is a challenging problem for construction and sustainability of physical soil and water conservation practices). Second, out of four community micro-watersheds in the Yegelw Kebele namely Dengab, Yewejet, Yefret and Tied micro-watersheds, one watershed namely, Dengab was randomly selected. Then, farmers in the selected watershed were stratified into adopters and non-adopters. Finally, based on the size of the sample determined from each group, simple random sampling technique was used to draw individual sample household heads from each group. Consequently, 44 farmers from adopters and 33 farmers from non-adopters totaling to 77 sample respondents were selected randomly.

\section{Methods of Data Analysis}

Data was analyzed both at household and plot level. The qualitative and quantitative data obtained through data collected were analyzed using descriptive statistics and Econometric model.

\section{Descriptive Analysis}

Descriptive statistics are important in order to have clear picture about the demographic, socio-economic, physical and institutional characteristics of sample respondents. One can compare and contrast the characteristics of adopter and non- adopter farmers using descriptive statics. Thus, in this study, descriptive statistics such as mean, standard deviation and percentage were used along with different tests and the econometric model to analyze the collected data. SPSS (statistical package for the social sciences) version 20 software was used to analyze the collected data.

\section{Specification of the Econometric Model}

For this study, a model that reflects the determinants of adoption of physical soil and water conservation practice on any particular farm was required. Different literatures on soil and water conservation investments were assessed to select suitable model.

Logit and probit models are well-known statistical techniques in which the probability of a dichotomous outcome (such as continued use or non-continued use) is linked to a set of explanatory variables that are hypothesized to affect the outcome (Neupane et al., 2002). Both are estimated by maximum likelihood, consequently, goodness of fit and inferential statistics are based on the log likelihood and chi-square test statistics. However, Pindyck and Rubinfeld (1981: P. 287) approved logistic probability function as computationally easier to use than the other types.

Therefore, a binary logistic regression model was used to study the determinants of adoption of physical soil and water conservation practice in the study area. The dependent variable in this case dummy (binary), which takes a value zero or one depending on adopters/adopted at least one of PSWC practices/or non- adopters/those who did not adopt any of these PSWC practices/.

However, the explanatory variables are either continuous or binary. Following Gujarati, (2004), the logistic distribution function for the adoption of SWC practices can be specified as:

Where,

$$
P_{i}=\frac{1}{1+e^{-Z_{i}}}
$$

$\mathrm{P}_{\mathrm{i}}$ is a probability of adopting a given practice by $\mathrm{i}^{\text {th }}$ household head and $\mathrm{Z}_{\mathrm{i}}$ is a function of explanatory variables $\left(\mathrm{X}_{\mathrm{i}}\right)$.

The logistic distribution function for not adopting of SWC practices can be specified as:

$$
1-P_{i}=\frac{1}{1+e^{Z_{i}}}
$$

Where $1-P_{i}$ is a probability of not adopting a given practice by $\mathrm{i}^{\text {th }}$ household head.

The odds to be used can be defined as the ratio of the probability that a farmer adopts the practice $P_{i}$ to the 
probability that he or she will not. That is,

$$
\frac{P_{i}}{1-P_{i}}=\frac{1+e^{Z_{i}}}{1+e^{-Z_{i}}}=e^{Z_{i}}=e^{b_{0}+\sum b_{i} x_{i}}
$$

Taking the natural logarithm of the above equation will result in what is known as the logit model as indicated below

$$
\ln \left(\frac{P_{i}}{1-P_{i}}\right)=\ln \left(e^{b_{0}+\Sigma b_{i} x_{i}}\right)=Z_{i}
$$

If the disturbance term $\mathrm{U}_{\mathrm{i}}$ is taken in to account the logit model becomes

$$
Z_{i}=b_{0}+\sum b_{i} x_{i}+u_{i}
$$

\section{Definition and measurement of variables}

Farmers' decision about PSWC practices can be conceived of having two components: whether to use PSWC practices or not. Both of these components are assumed to be influenced by a number of variables that are related to farmers' objectives and constraints. The dependent and independent variables employed in this analysis are listed below.

\section{Dependent variable}

The dependent variable in this study represents adoption of physical soil and water conservation technologies (such as soil bund, cutoff-drain, faynajju etc.) which is a dummy variable and takes a value of 1 for adopters and 0 otherwise. In this study adopters are those households who adopted at least one of these practices on their farm plots and use greater than one year without totally or partially removed the structures while those farmers who did not adopt conservation technologies less than one year and totally or partially removed any of these PSWC practices are considered non-adopter.

\section{Independent variables}

Independent variables of the model represent the variables which influence farmers' decision to use a given physical soil and water conservation practices such as personal, economical, institutional and bio-physical

\begin{tabular}{|c|c|c|c|}
\hline Variable & $\begin{array}{ll}\text { Nature of } \\
\text { variables }\end{array}$ & $\begin{array}{l}\text { Measurement and } \\
\text { definition }\end{array}$ & $\begin{array}{l}\text { Expected } \\
\text { effect }\end{array}$ \\
\hline \multicolumn{4}{|l|}{ Dependent variable } \\
\hline Adoption of PSWCs & Dummy & 1-if adopted; 0-otherwise & \\
\hline \multicolumn{4}{|l|}{ Independent variables } \\
\hline Sex of the household head & Dummy & 1-if male; 0-otherwise & - \\
\hline Farm size & Continuous & Hectare & + \\
\hline $\begin{array}{l}\text { Perception for erosion problem after } \\
\text { conservation structures built }\end{array}$ & Dummy & 1-reduced; 0-otherwise & + \\
\hline Ownership of farm plots & Dummy & 1-owned plots; 0 -otherwise & + \\
\hline Fertility of the plot & Dummy & 1-if high fertile; 0 -otherwise & - \\
\hline Family size & Continuous & $\begin{array}{l}\text { Number of people in the family in } \\
\text { adult equivalent (AE ) }\end{array}$ & - \\
\hline Participation in training & continuous & Training days per month & + \\
\hline Education level of household heads & Dummy & 1-literate; 0-otherswise & + \\
\hline Plot distance from the residence & Continuous & Measured in $\mathrm{Km}$ & - \\
\hline Slope of the plot & Dummy & 1-if steep slope; 0-otherwise & + \\
\hline Family labor & Dummy & $\begin{array}{l}\text { 1- if not labor shortage; } \\
0 \text { - otherwise }\end{array}$ & + \\
\hline Extension contact & Continuous & Contact days per month & + \\
\hline Age & Continuous & Measured in years & + \\
\hline
\end{tabular}
variables. Definition and measurement of variables included in the model are summarized as follows (Table 1).

Table 1: Definition and measurement of variables used in the model. 


\section{RESULT AND DISCUSSION}

Descriptive analysis

Demographic characteristics of sample respondents

\section{Age structure of sample households}

Age has an important role for the construction and implementation of improved physical soil and water conservation technologies based on different studies.

The mean age of the adopter farmers in the study micro-watershed was 46.77 years with standard deviation of 12.04. The mean age of non-adopter farmers was 51.3 years with standard deviation of 13.35 . The t-test result indicated that there is no statistically significant difference among adopters and non adopters in terms of their age (Table 5).

\section{Education status of sample households}

In the study area, five education levels of the respondent household heads $(\mathrm{HH})$ were identified. That is illiterate (cannot read and write), read and write only (no formal education), cluster (1-4 grade), linear (5-8 grade) and high school (9-10 grade). The distribution of adopter sample respondents in terms of literacy level has shown that 34.1 percent were illiterate, 29.50 percent could read and write, 20.50 percent attended 1 to 4 grade, 13.60 percent attended 5 to 8 grade and the remaining 2.30 percent attended 9 to 10 grade. With regards to non-adopters 39.40 percent were illiterate, 42.40 percent could read and write, while 81.80 percent attended formal education up to grade 10. The chi-square test for the level of adoption of physical soil and water conservation technologies among adopters and non-adopters indicated that there is insignificant difference in terms of educational level (Table 2).

Table 2: Distribution of sample respondents by educational status

\begin{tabular}{|l|c|c|c|c|c|c|c|}
\hline \multirow{2}{*}{ Educational status } & \multicolumn{2}{|c|}{ Adopters } & \multicolumn{2}{c|}{ Non-adopters } & \multicolumn{2}{c|}{ Total } & $\chi 2$ \\
\cline { 2 - 7 } & Number & $\%$ & Number & $\%$ & Number & $\%$ & 3.07 \\
\hline Illiterate & 15 & 34.1 & 13 & 39.4 & 28 & 36.4 \\
\hline Read and write only & 13 & 29.5 & 14 & 42.4 & 27 & 35.1 \\
\hline 1-4 grade & 9 & 20.5 & 3 & 9.1 & 12 & 15.6 \\
\hline 5-8 grade & 6 & 13.6 & 2 & 6.1 & 8 & 10.4 \\
\hline 9-10 grade & 1 & 2.3 & 1 & 3 & 2 & 2.6 \\
\hline Total & 44 & 100 & 33 & 100 & 77 & 100 & \\
\hline
\end{tabular}

Source: Own survey data, 2018.

\section{Sex of sample households}

The sample households were composed of both male and female household heads. The survey results revealed that among the total sample household heads 40 (92.21 percent) were male headed and the remaining 4 (7.79 percent) were female headed. The proportion of male-headed households was 91 percent for adopters and 93.94 percent for non-adopters. Chi-square test was conducted to see the association of sex and participation in physical soil and water conservation technologies and it was not significant $\left(\chi^{2}\right.$ value $\left.=0.24\right)$.

\section{Family size of sample house holds}

The mean family size of sampled adopters was about 3.98 persons (measured in adult equivalent) with standard deviation of 1.36. The mean family size of non adopters was about 4.79 persons with standard deviation of 1.43. The t-test result indicated that there was statistically significant difference among adopters and non-adopters in terms of their mean family size (Table 5).

\section{Perception of respondents on physical soil and water conservation practices}

As indicated on Table 3, perceptions of the total sample adopter households on the degree of erosion after conservation structures were reduced, no change and I don't know and the responses contributed 81.82 percent, 11.36 percent and 6.82 percent, respectively. On the other side, from the total non-adopter household heads, aggravated, reduced, no change and I don't know responses contributed 9.09 percent, 72.73 percent, 15.15 percent and 3.03 percent, respectively. The Chi-square test result indicated that there is no significant difference between the two groups regarding the perception on physical soil and water conservation practices. 
Table 3: The perception level of sample respondents and adoption of improved physical soil and water conservation practices

\begin{tabular}{|c|c|c|c|c|c|c|c|}
\hline \multirow{2}{*}{$\begin{array}{l}\text { Perception of respondents on erosion after } \\
\text { the construction of structures }\end{array}$} & \multicolumn{2}{|c|}{ adopters } & \multicolumn{2}{|c|}{ Non-adopters } & \multicolumn{2}{|c|}{ Total } & $\chi^{2}$ \\
\hline & Number & $\%$ & Number & $\%$ & Number & $\%$ & \multirow[t]{5}{*}{4.93} \\
\hline Aggravated & 0 & 0 & 3 & 9.09 & 3 & 3.90 & \\
\hline Reduced & 36 & 81.82 & 24 & 72.73 & 60 & 77.92 & \\
\hline No change & 5 & 11.36 & 5 & 15.15 & 10 & 12.99 & \\
\hline I Don't know & 3 & 6.82 & 1 & 3.03 & 4 & 5.19 & \\
\hline
\end{tabular}

Source: Own survey, 2018.

\section{Scio-economic factors}

\section{Labor availability}

Out of the total respondents, 33 adopters ( 75 percent) and 22 non-adopters $(66.67$ percent) reported that they had labor shortage. On the other hand, 11 adopters ( 25 percent) and 11 non-adopters ( 33.33 percent) were not faced with labor shortage. The Chi-square value $(0.64)$ indicated that there is no difference between adopters and nonadopters with regard to labor availability.

\section{Land size}

The average farm size for adopters was 1.66 hectare with standard deviation of 0.925 , while that of non-adopters was 1.55 hectare with standard deviation of 0.93 . The mean difference between adopters and non-adopters with respect to size of land holding was statistically insignificant (Table 5).

\section{Physical factors}

\section{Slope and fertility level of farm plots}

Regarding the slope of farm plots, the survey result indicates that of the total adopters 100, 46, and 15 reported that their farm plots are gentle, flat and steep, respectively. And of the total non-adopters, 85, 16, and 6 reported that their farm plots are gentle, steep and flat, respectively. The Chi-square test for the level of farm plots slope between the two groups was found to be significant (Table 4).

Regarding fertility of farm plots, $18.63 \%$ of the sampled adopters have low fertility plots, $65.2 \%$ have medium fertility plots and the rest $16.14 \%$ have high fertility plots during the survey time. Of total non adopters, $8.41 \%$ have low fertility plots, $60.75 \%$ have medium fertility plots and the remaining $30.84 \%$ have high fertility plots. The Chi-square result indicated that there is statistically significant difference among adopters and non adopters in terms of fertility level of farm plots (Table 4).

Table 4: Distribution of farm plots by slope category and level of fertility

\begin{tabular}{|c|c|c|c|c|c|}
\hline \multirow[t]{2}{*}{ Description } & \multicolumn{2}{|c|}{ Adopter } & \multicolumn{2}{|c|}{ Non-adopter } & \multirow{2}{*}{$\frac{\chi 2 \text { value }}{6.53}$} \\
\hline & Number & $\%$ & Number & $\%$ & \\
\hline \multicolumn{5}{|l|}{ Slope category } & \\
\hline Flat & 46 & 28.57 & 6 & 5.61 & \\
\hline Gentle slope & 100 & 62.11 & 85 & 79.44 & \\
\hline Steep & 15 & 9.32 & 16 & 14.95 & \\
\hline \multicolumn{5}{|l|}{ Fertility } & \multirow[t]{4}{*}{11.91} \\
\hline Low & 30 & 18.63 & 9 & 8.41 & \\
\hline Medium & 105 & 65.22 & 65 & 60.75 & \\
\hline High & 26 & 16.15 & 33 & 30.84 & \\
\hline
\end{tabular}

\section{Farm plot Distance}

On average, adopters were located $0.53 \mathrm{~km}$ distances whereas non-adopters were about $0.56 \mathrm{~km}$ far away from the farm plots with standard deviation of 0.44 and $0.45 \mathrm{~km}$, respectively. The mean difference between the two groups was found to be insignificant (Table 5).

\section{Institutional factors}

\section{Extension contact}

The monthly average number of extension contact for participants and non-participants were 1.89 and 1.33 , with standard deviation of 0.81 and 0.54 , respectively. The difference in extension contact between the two groups was statistically tested and found to be significant at 1 percent probability level (Table 5). 
Training participation of the respondents

The monthly average number of training by adopters and non-adopters were 1.48 and 1.24 with standard deviation of 0.73 and 0.44 , respectively. The mean difference between the two groups was significant at 10 percent significance level (Table 5).

\section{Ownership of farm plots}

This is a dummy variable which takes 1 for own land and 0 otherwise. The survey result indicates that of the total 171 plots of land managed by adopters, 161 plots ( 94.15 percent) were own land and the rest 5 plots were rented in and the remaining 5 plots were share cropped. On the other hand, of the total 108 plots managed by non-adopters, 99 (91.67 percent) were own land and 1 plot and 1 plot were rented and share cropped, respectively. Accordingly, the Chi-square test for land ownership between the two groups was tested and the differences are found to be statistically significant (Chi- square value $=6.42$ ).

Table 5: Summary of t-test for means differences of continuous variables between adopters and nonadopters of the watershed

\begin{tabular}{|l|l|c|c|c|c|c|}
\hline \multirow{2}{*}{ Variables } & \multirow{2}{*}{ Units } & \multicolumn{2}{|c|}{ Adopters } & \multicolumn{2}{c|}{ Non-adopters } & \multirow{2}{*}{ t-value } \\
\cline { 3 - 6 } & & Mean & Std. Dev. & Mean & Std. Dev. & \\
\hline Age & Year & 46.77 & 12.04 & 51.30 & 13.35 & 1.54 \\
\hline Family size & Number & 3.98 & 1.36 & 4.79 & 1.43 & $-2.51^{* *}$ \\
\hline Farm size & Hectare & 1.66 & 0.925 & 1.55 & 0.93 & -0.52 \\
\hline Plot distance & Kilometer & 0.53 & 0.44 & 0.56 & 0.45 & 0.29 \\
\hline Monthly extension contact & Number & 1.89 & 0.81 & 1.33 & 0.54 & $-3.63^{* * *}$ \\
\hline Monthly training & Number & 1.48 & 0.73 & 1.24 & 0.44 & $-1.79^{*}$ \\
\hline
\end{tabular}

$* * *, * *$ and $*$ Statistically significant at 1 percent, 5 percent , and 10 percent significance level, respectively

\section{Econometric Results Analysis}

Factors Affecting the Adoption of Physical Soil and Water Conservation Technologies

The maximum likelihood estimation method was used to estimate the coefficients of the explanatory variables in the logit model. To estimate the model, thirteen variables (six continuous and seven dummy) were included. The result of the binary logistic regression model indicated that seven variables were found to have positive and significant influence on the adoption of physical soil and water conservation technologies. These variables are education, ownership of farm plots, slope, farm size, extension contact, training and perception. While, variables such as age, distance and fertility influenced adoption of physical soil and water conservation technologies negatively and significantly at conventional significant levels (Table 6).

Table 6. Maximum likelihood estimates of binary logit model on determinants of adoption of physical soil and conservation technologies

\begin{tabular}{|l|c|c|c|l|c|}
\hline Explanatory variables & Coefficient & S.E. & Wald & \multicolumn{1}{c|}{ Sig. } & Odds Ratio \\
\hline Sex & -0.735 & 0.581 & 1.599 & 0.206 & 0.479 \\
\hline Age & -0.047 & 0.013 & 13.043 & $0.000^{* * *}$ & 0.954 \\
\hline Education & 0.147 & 0.064 & 5.306 & $0.021^{* *}$ & 1.159 \\
\hline Family size & -0.128 & 0.104 & 1.520 & 0.218 & 0.880 \\
\hline $\begin{array}{l}\text { Ownership of farm } \\
\text { plots }\end{array}$ & 1.049 & 0.572 & 3.368 & $0.066^{*}$ & 2.854 \\
\hline Distance & -0.565 & 0.289 & 3.824 & $0.051^{*}$ & 0.569 \\
\hline Soil fertility & -0.734 & 0.405 & 3.289 & $0.070^{*}$ & 0.480 \\
\hline Slope & 0.778 & 0.356 & 4.758 & $0.029^{* *}$ & 2.176 \\
\hline Farm size & 0.692 & 0.357 & 3.749 & $0.053^{*}$ & 1.997 \\
\hline Extension contact & 0.403 & 0.214 & 3.538 & $0.060^{*}$ & 1.496 \\
\hline Training & 0.416 & 0.233 & 3.205 & $0.073^{*}$ & 1.517 \\
\hline Perception & 0.782 & 0.281 & 7.749 & $0.005^{* * *}$ & 2.185 \\
\hline Labor & 0.301 & 0.340 & 0.783 & 0.376 & 1.351 \\
\hline Constant & -2.032 & 1.143 & 3.158 & 0.076 & 0.131 \\
\hline
\end{tabular}

Note: $* * *, * *, *$, significant at $1 \%, 5 \%$, and $10 \%$, respectively

Source: SPSS output

Chi-square $=57.685$

$-2 \log$ likelihood $=312.034^{\mathrm{a}}$

Percentage correctly predicted $=69.0$ 


\section{CONCLUSIONS AND RECOMMENDATIONS \\ Conclusions}

Implementation of physical soil and water conservation technologies is fundamental to restore degraded lands and to prevent soil and water losses in advance due to various social and environmental phenomena. However, there was a gap in adoption of these technologies in Dengab micro-watershed. Estimation of determinants of decision to adopt physical soil and water conservation technologies was employed using 13 hypothesized explanatory variables with the help of logit model.

The result showed that education level of the household head, training, perception of farmers on physical water and soil conservation technologies, extension contact, ownership of farm plots, soil fertility, slope of the plot, age, farm size and distance to the farm plots were found to significantly affect the adoption decision of farmers.

\section{Recommendation}

It is found that physical soil and water conservation works are more adopted by households who own their own lands than those who either rent in lands or use share cropping with others. Therefore, those farmers who rent out their lands must inform the renters to use the lands properly or firstly the two parties should make agreements about the management of farm plots. The government and NGOs should focus on this type of farming system on both sides with accountability on physical soil and water conservation practices on farm plots.

The farmers' ideas, local experience, and perceptions were extremely ignored. Overall results indicated that the farmers' willingness to accept and invest on soil and water conservation technologies was strongly linked with physical, socioeconomic, institutional and attitudinal factors. Therefore, any soil and water conservation plans should consider the farmers' willingness and factors impeding their practices before introducing these technologies; create awareness on the farmers about the overall benefits and challenges of the technologies and follow downtop approach and include farmers in any decision making processes.

\section{REFERENCES}

Anley Y, Bogale A, Haile-Gabriel A. 2007. Adoption Decision and Use Intensity of Soil and Water Conservation Measures by Smallholder Subsistence Farmers in Dedo District. Western Ethiopia Land Degrad Develop 18:289-302

Assefa \& Bork. 2015. E. Assefa, H.R. Bork Farmers' perception of land degradation and traditional knowledge in Southern Ethiopia-resilience and stability Land Degradation and Development

Atnafe, A. D., Ahmed, H. M., \& Adane, D. M. 2015. Determinants of adopting techniques of soil and water conservation in Goromti Watershed, Western Ethiopia. Journal of Soil Science and Environmental Management, 6(6), 168-177. https://doi.org/10.5897/JSSEM15.

Balana, B.B., Mathijs, E., andMuys,B. 2010.Assessing the sustainability of forest management: an application of multi-criteria decision analysis to com- munity forest sin nor thern Ethiopia. J. Environ. Manage. 91, 12941304.doi: 10.1016/j.jenvman.2010.02.005.

Blanco.R, Lal, R. 2008. Principles of Soil Conservation and Management, Springer, New York, p. 285.

Derjew, Bekabil, \& Wagayehu. 2013. F. Derajew, F. Bekabil, B. Wagayehu Determinants of the use of soil conservation technologies by smallholder farmers: The case of HuletEjuEnesie district, East Gojjam zone, Ethiopia.

FAO (Food and Agriculture Organization of the United Nations).1986. Ethiopian Highlands Reclamation Study, Ethiopia Final Report, FAO Rome.

Gessesse et al. 2015. G.D. Gessesse, R. Mansberger, A. Klik Assessment of rill erosion development during erosive storms at Angereb watershed, Lake Tana sub-basin in Ethiopia.

Kebede, B. A., Black, T. G., Mideksa, D. D., \& Nega, M. B. 2016. Soil and water conservation practices : economic and environmental effects in Ethiopia, 4(1), 169-177.

Melkie Erkie.2016. Asessment of Farmers' awareness and adoption on soil and water conservation practices: the case of Borebor Micro watershed, Dera District, Ethiopia. Unpublished paper.

Meseret, D., \& Amsalu, A. 2017. International Soil and Water Conservation Research Determinants of farmers ' perception to invest in soil and water conservation technologies in the North-Western Highlands of Ethiopia is. International Soil and Water Conservation Research, 5(1), 56-61. https://doi.org/10.1016/j.iswcr.2017.02.003

Mulie Alemu Bizunhe. 2012. Adoption of soil and water conservation practices on farmlands: the case of Karita Wuha Watershed, West Belessa District, North Gondar, Ethiopia.

Neupane, R.P., Sharma, K.R., Thapa, G.B. 2002. Adoption of agro forestry in the hills of Nepal: A logistic regression analysis. Agricultural Systems 72(3):177-196.

Pindyck, R.S., Rubinfeld, D. L. (1981). Econometric models and economic forecasts. McGraw-Hill, London.

Rehema Seenga.2014. Factors influencing adoption of soil conservation measures, sustainability and socioeconomic impacts among small-holder farmers in mbeya rural district Tanzania. Unpublished Master's Thesis, 
School of Sokoine University of agriculture. Morogoro, Tanzania.

Tesfaye \& Brouwer (2012) A. Tesfaye, R. Brouwer Testing participation constraints in contract design for sustainable soil conservation in Ethiopia Ecological Economics, 73 (2012), pp. 168-178

Teshome, A., Graaff, J. De, \& Kassie, M. 2016. Household-Level Determinants of Soil and Water Conservation Adoption Phases : Evidence from North-Western Ethiopian Highlands.Environmental Management, 57(3), 620-636. https://doi.org/10.1007/s00267-015-0635-5

Yegelaw Kebele Agricultural and Rural Development Office. 2018. Annual report 